\title{
Michael Reid
}

\section{Does the Reform of}

English Local Government Contain Lessons for New

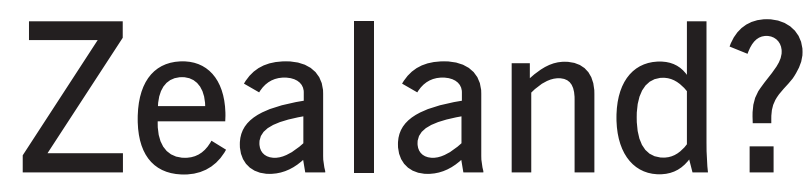

In recent decades, despite differences of form and function, local government reform in England and New Zealand has exhibited very similar characteristics, with each system borrowing from the other: changes introduced in one country have usually been followed a few years later in the other. ${ }^{1}$ It is interesting, then, that at a time when both countries have centre-right governments, that trend now appears to have changed, and local government policy is showing signs of major divergence. Where the New Zealand government appears to believe that only by greater 'handson' involvement can the nation's economic development be guaranteed, the British government has taken quite the opposite view, identifying the country's high level of centralisation (second only to New Zealand's in the OECD) as the problem, not the solution. ${ }^{2}$ The new ConservativeLiberal Democrat government has set itself the objective

of unwinding years of increasing centralisation and removing what it calls the culture of inspection characterising central government's relationship with local government. New Zealand, in contrast, appears to be committed to the opposite path, with greater top-down inspection and a continuing accretion of powers and decision making by the centre.

Historically, policies towards local government have been remarkably similar. The British government drove through a programme of amalgamation in the early 1970s, creating the largest councils in Europe. New Zealand followed suit a decade or so later. Where Margaret Thatcher's government shifted functions from councils to stand-alone quangos (for example, water and waste water), New Zealand created local authority trading enterprises to run anything having a commercial focus. Both countries drew extensively from the private sector as they sought to modernise their local government sectors, with the United Kingdom opting for compulsory competitive tendering and extensive performance benchmarking, while New 
Zealand focused more on strengthening transparency through techniques such as annual planning and reporting. In the mid-9os the requirement that $\mathrm{New}$ Zealand councils adopt long-term financial strategies morphed, four years later, into an obligation on English councils to adopt community strategies. ${ }^{3}$ This synergy or complementarity appears to be ending.

With the election in both countries of centre-right governments, local government reform appears to be headed
British economy for the challenges of the new millennium. The philosophical underpinning of the government's new approach is captured in its enthusiasm for what it refers to as the 'Big Society', an overarching policy agenda that has three core planks:

- Social action: a successful society depends on the decisions of thousands of people, therefore government should foster and support a new culture of voluntarism, philanthropy and social action.

\section{Although local government in the UK was given a 'power of well-being' in 2000 , recent judicial decisions have interpreted the power narrowly, perhaps more narrowly than Parliament intended ...}

in quite different directions. While government policy in New Zealand appears focused on 'winding back' council discretion through what might be called a policy of a thousand cuts, David Cameron's Conservative-Liberal Democrat coalition has made explicit its intention to roll back the centralism that was a feature of its predecessors. To quote Cameron before the release of the Conservatives' local government green paper in February 2009:

I mean we've got a government now that has set up this enormous regional bureaucracy which I think we can get rid of and drive those powers down to the local level. We've got a government that issues so many orders and instructions and bureaucratic targets to local government, we can sweep a lot of that away. (Cameron, 2009a)

The British government's enthusiasm for removing restrictions on local government, promoting greater devolution and empowering communities arguably represents a paradigm shift that they hope will not only distinguish the new government from the overwhelming interventionism of New Labour and its predecessors, but also prepare the a ground-breaking shift in power to councils and communities overturning decades of central government control and starting a new era of people power ... For too long, everything has been controlled from the centre - and look where it's got us. Central government has kept local government on a tight leash, strangling the life out of councils in the belief that bureaucrats know best. (Department for Communities and Local Government, 2010)

Cameron reinforced the argument when he stated that 'these changes add up to a massive redistribution of power from central government to local government - just like our plan to give our cities real civic leadership through directly elected mayors and to put policing under local control' (Cameron, 2009b). To achieve this fundamental shift in authority the bill offers something of a 'grab bag' of measures which would directly affect English local authorities (see Appendix 1). ${ }^{4} \mathrm{~A}$ number of them are discussed below.

One of the more conventional proposals in the bill involves the introduction of a power of general competence. Although local government in the UK was given a 'power of wellbeing' in 2000, recent judicial decisions have interpreted the power narrowly, perhaps more narrowly than Parliament intended and certainly more narrowly than desired by councils (even though there is little evidence of councils actually making use of the power). New Zealand councils, in comparison, have had a form of general empowerment since 2002, and, although criticised by many in and outside Parliament as responsible for growing council expenditure, the power has been left largely untouched. General empowerment is strongly supported by councils in the UK; other provisions have not been given the same regard. For example, the bill will allow residents to require councils to hold referenda on any local issue, as well as require mandatory referenda should a council wish to increase property taxes beyond a set amount. ${ }^{5}$

Where the bill begins to look particularly radical is in the proposal 
to empower neighbourhoods and community groups to set their own policies and rules. For example, one provision will allow neighbourhoods to 'opt out' of council planning rules and regulations, which includes the right to develop their own 'neighbourhood plans', with government assistance, to control development, regardless of the council's overall plan. The aim is to encourage parish councils and 'neighbourhood forums' to come together to decide where new shops, offices or homes should go and what green spaces to protect - to be voted on by local people in local referenda - and they will also be able to define developments which should have automatic planning permission. Debate continues as to whether this will result in a flood of NIMBYism ('not in my back yard') or, as ministers expect, will relax planning rules to increase development, given fewer controls on environmental and social effects. The bill also removes a number of national bodies and processes, for example disbanding the regional spatial strategies (in direct contrast to New Zealand, which is toying with the idea of introducing regional spatial strategies) and the Infrastructure Planning Commission (New Zealand has recently set up an Infrastructure Unit located within Treasury). The intention is to replace those bodies with what the government describes as more responsive democratic mechanisms.

In a further effort to empower communities, the bill allows groups of local citizens to take over 'failing' local public services, such as council housing and community facilities, whether they are run by the council or by a government department. Councils will be required to compile a list of public and private assets that are deemed to have community value. Should these assets be put up for sale, communities will have six months to prepare a bid to purchase them; assets might include the local pub, post office or community centre. ${ }^{6}$ In addition, the bill will establish a 'community right to challenge' to help different groups run local services if they want to. Voluntary groups, social enterprises, parish councils and others will be able to express an interest in taking over council-run services, for example libraries, with a requirement on the local authority to consider the proposal.

\section{The direction of reform in New Zealand}

Where the coalition government in Britain appears committed to reversing the country's centralised approach to decision making by empowering councils and communities, there are reasonable arguments to say that the opposite is occurring in New Zealand, although policy tends not to be driven by any form of grand narrative and contains
- a gradual shift of funding away from local roads to the state highways; an investigation into road classification systems that has the potential to reduce local discretion regarding levels of service.

Ministry for the Environment:

- The establishment of the Environmental Protection Agency to consider proposals for projects of national significance (a less than technical term).

- The creation of a ministerial override power for aquaculture applications.

\section{... recent governance decisions reflect a greater willingness to intervene when sub-national government fails to live up to the centre's expectations.}

its share of internal tensions. It is also helpful to remember that this centralising tendency is not new. John Cookson dates it back to the early 1930s, a point in the nation's history when nearly $50 \%$ of all public expenditure was made by local government; today that figure is closer to $10 \%$. It is a trend that has continued through successive governments, but which might be seen to have increased speed over the last two years with a government that has succumbed to the rhetoric of the 'national interest' to justify an increasing and often unprecedented interference in local affairs. Consider the range of recent initiatives essentially designed to reduce council discretion: Department of Building and Housing:

- greater standardisation of building regulations and processes, as well as a desire to create a small number of 'super' (non-local) building regulators.

Department of Internal Affairs:

- the creation of standardised performance measures for the five major infrastructural activities delivered by councils.

The New Zealand Transport Agency:
- An enthusiasm for national policy statements and national environmental standards that by definition reduce local and regional discretion.

Ministry of Health

- A commitment to national drinkingwater standards.

In addition, recent governance decisions reflect a greater willingness to intervene when sub-national government fails to live up to the centre's expectations. Examples include the decision to replace the democratically-elected members of the Canterbury Regional Council with government-appointed commissioners; the acquisition of quite draconian powers through the Rugby World Cup 2011 Empowering Act 2010; and the establishment of the Canterbury Earthquake Recovery Authority (CERA). While noting that in some cases the government has few choices, given the severity of the challenges faced by communities, the propensity to take a 'command and control' approach is a concern, for no other reason than that it obscures the constitutional separation between the two levels of government. Even the establishment of the super city, Auckland, with its focus of strong, 
unified government for that city and the requirement to adopt a regional spatial plan, sits in contrast to the British government's decision to halt moves by its predecessor to amalgamate local authorities into larger unitary councils and to disband the regional spatial planning agencies.

While official policy towards local government appears to be less tolerant towards local difference and discretion, we should acknowledge those policy change in local government working (Filkin et al., 2000). A related concept is the principle of subsidiarity which has been adopted by the European Union when determining the distribution of responsibilities between states and subnational governing bodies. It was also a recommendation of the New Zealand Royal Commission on Social Policy, which stated that "no organisation should be bigger than necessary, and nothing should be done by a larger and higher unit that

\section{... one of the key lessons we might take from this bill is a general view that UK councils are simply too big and bureaucratic.}

initiatives that echo the English focus on decentralisation and seek to reduce central control by empowering communities. Many of these are driven by information asymmetry concerns: for example, the community response forums, established by the minister of social development, which appear to be an attempt to utilise local/regional intelligence with regard to the allocation of family and community services funding; similarly the Whānau Ora programme. In a different policy context, the minister for the environment's Land and Water Forum is attempting to address complex environmental issues by seeking a consensus from the major stakeholders, as opposed to the more traditional approach of top-down policy. Common in both cases, of course, was the absence of organised local government.

\section{Understanding the philosophy}

Policy towards local government in the United Kingdom has coalesced around the relatively nebulous concept of new localism, with the major parties having been competing to be seen as the new localist champion.' 'New' localism (in contrast to 'old' localism) promotes the involvement of local people in governance (not simply councillors); high-quality vertical as well as horizontal linkages; community leaders rather than primarily service producers; and a fundamental can be done by a lower and smaller unit' (Royal Commission on Social Policy, 1988, p.806). However, the concept has had a limited impact in New Zealand, unlike in Europe where it has been incorporated into the European Charter of Local SelfGovernment. $^{8}$

Localism is not without its critics. Cashin (2000), for example, argues that voters behave more self-interestedly when decision-making authority is brought closer to them, citing a common practice in the United States for well-off suburbs to incorporate as separate authorities in order to avoid the cost of supporting the urban poor. She uses the phrase 'tyranny of the favoured quarter' to describe the increasing fragmentation of local governance in many states that has resulted in metropolitan regions stratified by race and income. Localism, in this context, represents extreme parochialism and a political NIMBYism. Localist forms of governance are also poorly placed to deal with externalities and spillovers, such as where one community freeloads by using services provided by its neighbour. Regional coordinating mechanisms are often required for those services which need an economy of scale (see also Dollery et al., 2005). The interesting thing about the new localist movement that has influenced local government policy throughout the United Kingdom is its attempt to address these shortcomings by distinguishing between local government as a provider of services and local government as an enabling agency using its full range of powers to influence service providers to enhance the quality of life in localities.

Perhaps one of the key lessons we might take from this bill is a general view that UK councils are simply too big and bureaucratic. For example, Geoff Mulgan, until recently the chief executive of the think tank the Young Foundation and visiting professor at the London School of Economics, is reputed to have commented that local government in England was neither local nor government - a telling observation on its distance from citizens and its general lack of decision-making discretion which helps explain that government's dual interest is in strengthening local democracy and giving power back to the people.

Although the Decentralisation and Localism Bill is still a work in progress and may be subject to major change as it makes its way through both houses of Parliament, it represents a significant change in the relative roles of central government, local government and communities. Yet many of the proposals have never been tried before and it remains to be seen whether they are practical. For example, will there be enough volunteers with the time and skills to 'take over' local services, such as libraries, and how will accountability be exercised? The bill makes a number of assumptions about the capacity and willingness of citizens to take over local services that are yet to be tested. Despite the fact that much of the overall package rests on somewhat heroic assumptions, it represents a range of innovative measures that attempt to shift decision making from Westminster to local authorities and further to smaller communities and groups and citizens themselves.

English councils have been highly critical of the bill, despite their enthusiasm for its overall objectives, with $81 \%$ indicating they are unsupportive of the government and 91\% disagreeing with the statement that Eric Pickles and his ministers will listen to local government. Writing in the Guardian, Simon Jenkins 
stated: 'I have read parliamentary bills all my life, but the localism one is the most wretched capitulation to a single lobby I know. It is a junk heap of cliché.' ${ }^{9}$ Other critics have noted that despite the bill's objectives, ministers retain more than 200 call-in powers over council decision making and operations. For example, under the bill the secretary of state will have a general power to order councils to pay fines to the European Union. Certainly councils' views towards change have been coloured by massive cuts in council income, nearly $80 \%$ of which come from the state forcing significant reductions in local services. ${ }^{10}$

One of the interesting contrasts between politics in the United Kingdom and New Zealand is the lack of an organised lobby for what we might call the localist agenda which has dominated local government policy discourse in the United Kingdom for more than a decade. Led by one of that nation's more successful think tanks, the New Local Government Network, the call for a 'new localism' has been endorsed by all the major political parties, with Eric Pickles, the architect of the Localism Bill, quoted as saying as early as 2003 that 'we were absolutely wrong. We're born-again local'." The Localism Bill seems to be unique when considered in the context of international local government reform, although, given that England is the second most centralised state in the OECD, the government believes it is faced by a set of unique challenges.

If we were to try and locate the policy direction within a broader strain of political thinking it might be worth looking at the degree to which the concept of the 'Big Society' echoes the main strands of communitarian thought, and even a nostalgia for the idea of selfgoverning communities, an idea that is particularly prevalent in the United States. The idea that public decision making is something that should belong to a class of experts, and therefore be done nationally, seems to have been on the rise in the last century, which has seen public affairs gradually removed from the reach of the average citizen to become a matter for policy elites operating at the highest levels of government (Novak,
1996). Novak points to the rise of atlarge city-wide systems of representation which 'handed governance to corporate and professional elites [who] possess a scientific and rational view of governance' (ibid., p.16), and to a resurgence of interest in response in more localised forms of organisation and decision making, including nostalgia for the Jeffersonian idea of participatory democracy - citing President Bush senior's description of America as a nation of communities and President Clinton's view of society as a series of organic networks.
While parties like ACT argue for reducing the power of the state and empowering citizens, locally-elected government is seen to be part of the problem rather than the solution. New Zealand suffers from a lack of organised think tanks and policy networks on both the left and right of politics committed to a localist agenda. This is hard to understand, given that local government investment in infrastructure made such a crucial contribution to making this country one of the richest in the world. However, it is a story that universities

\section{Whether the Localism Bill results in empowered councils and communities or ends up as a Clayton's localism, it offers us a fascinating case of public sector reform heading in the opposite direction to our own.}

\section{Conclusion}

The reversal in the state's approach to local government in the United Kingdom reflects a larger programme than simply a desire to strengthen the role of councils; indeed, some of the proposals being considered have caused considerable concern among councils as they specifically seek to bypass formal local government. The key difference, at least at a rhetorical level, is the recognition that local representative government should play a larger role in what Michael Lyons (2007) called 'place shaping' (the creative use of its powers to promote the general well-being of a community and its citizens), free from the direction of Whitehall officials. In comparison, it is interesting that New Zealand, regarded as the most centralised country in the OECD (putting aside city-states like Singapore, which, coincidentally, is currently facing calls for the re-establishment of local government), has failed to create the same momentum. In fact, only recently there were calls for central government to appoint members to regional councils to ensure greater consistency. ${ }^{12}$ have seldom bothered to investigate and few of our histories found interesting enough to recount.

Whether the Localism Bill results in empowered councils and communities or ends up as a Clayton's localism, it offers us a fascinating case of public sector reform heading in the opposite direction to our own. If nothing else, we can learn from the British experience, and, who knows, similar measures might be introduced here. An opportunity exists with the government's 'Smarter Government, Stronger Communities' review currently being undertaken by the Department of Internal Affairs. The review was heralded by the minister of local government as a first principles review of local government and given a time frame of more than three years. While its terms of reference include a review of local government functions, their failure to include central government functions and whether or not they would be more effectively handled by local government is likely to diminish the likelihood that its recommendations will reflect a localist approach.

The challenge for policy makers in New Zealand is that the national interest, 
whether defined as the government of the day's strategic objectives or a broadbased well-being indicator, will not be best served by strengthening control at the centre. We need to remember that those countries we aspire to replicate in terms of standard of living - Switzerland, the United States and the Scandinavian countries - all have one thing in common: they decentralise significantly, providing communities with much greater say about local matters. It's not a new idea: as the introduction to New Zealand's first Municipal Corporations Bill (1841), which was the main item of business on the new Legislative Council's second day 170 years ago, stated:

the inhabitants themselves are best qualified, as well by their more intimate knowledge of local affairs, as by their direct interest therein, to provide for the wants and needs of their respective settlements. ... the central government would thus be deprived of the power of partiality in its legislation; it would be relieved from the necessity of much petty legislation; while at the same time, the prosperity of the country at large, would be promoted by the honourable rivalry which would spring up among the various settlements, thus entrusted with the unfettered management of their own local affairs. (Legislative Council, Wednesday, 29 December 1841, quoted in Carman, 1970)

\footnotetext{
1 It might also be argued that New Labour's enthusiasm for directly-elected mayors is another example of England borrowing from the New Zealand approach. Note also the similarity between the purpose statement in the Local
}

Government Act 2002 and the power of well-being in the Local Government Act 2000 (UK).

2 See Economist, 31 Oct. 2009, p.59.

3 Discussions between the author and the Local Government Information Unit.

4 Local government in Wales and Scotland is devolved to their respective assemblies.

5 Ironically, similar referenda were promoted here by Rodney Hide when minister of local government. Cabinet failed to support the idea.

6 Controversially, the bill also requires councils to compensate owners who lose value due to costs incurred or delayed sales (Local Government Chronicle, 4 Aug. 2011).

7 Political localism should be distinguished from the recent interest in what might be called ecological localism, which encapsulates a desire to establish local economies not dependent on imported goods, an anti-globalisation movement.

8 See http://conventions.coe.int/Treaty/en/Treaties/html/122. $\mathrm{htm}$.

9 Guardian online, 28 July 2011. Jenkins failed to articulate which lobby group the government had capitulated to, whether the champions of localism or the development community which expects to gain by the relaxation of planning rules.

10 In contrast, councils receive $11 \%$ of their income from the state, and even that figure is problematic as it represents local government's share of the petrol taxes and various road charges collected by central government, so is not technically a transfer at all.

11 www.economist.com/node/1749999.

12 Land and Water Forum, Radio New Zealand news, 7.00 am, 28 Sept. 2011.

\section{Apendix 1: $\quad$ Decentralisation and Localism Bill}

\begin{tabular}{|c|c|c|}
\hline Headings & Content & Relevance to New Zealand \\
\hline $\begin{array}{l}\text { Running local } \\
\text { services }\end{array}$ & $\begin{array}{l}\text { The bill will establish a 'community right to challenge' to help different groups run } \\
\text { local services if they want to. Voluntary groups, social enterprises, parish councils \& } \\
\text { others will be able to express an interest in taking over council-run services - the local } \\
\text { authority will have to consider it. }\end{array}$ & No equivalent measure exists in New Zealand. \\
\hline
\end{tabular}

Buying local assets The bill provides an opportunity for local community groups to bid to buy buildings or land which are listed, by the local authority, as assets of community value, e.g. post offices, pubs. Locals will be able to place certain buildings on a 'most wanted' list, and if those buildings are put up for sale they would have to be given time to develop a bid and raise the money.

No New Zealand equivalent.

No New Zealand equivalent.

Councils, police and fire authorities which propose an increase in council tax beyond ceiling set by government would automatically face a referendum of all registered voters in their area.

Local referenda The bill gives people, councillors and councils the power to instigate a local referendum on any local issue. Although these referenda will be non-binding, local authorities and other public authorities will be required to take the outcomes into account during decision making.

Powers for councils The bill gives local authorities a 'power of competence', which is the right to do 'anything
apart from that which is specifically prohibited'. The intention is to free councils from
'Whitehall diktat' and help them 'innovate'. The bill also includes measures to allow
councils to go back to being run by committees - instead of by a mayor and cabinet.
(Councils have three governance models which they can use; this would create a
fourth.)

Removal of the predetermination requirement
The bill makes it clear that if a councillor has given a view on an issue, this does not show that the councillor has a closed mind on that issue, so that if councillors have campaigned on an issue or made public statements about their approach to an item of council business, they will be able to participate in discussion of that issue in the council and to vote on it if it arises in an item of council business requiring a decision. It also provides for the establishment and maintenance of a register of members' interests.
No equivalent in New Zealand, although councils have the discretion to hold polls and referenda and can resolve to do so themselves or after a community request. Referenda are frequently used to gauge support, for the introduction of, for example, fluoride.

New Zealand councils already have a general power of competence and have full discretion when deciding whether or not to establish committee structures. The position of mayor has been created by statute. (England has approximately 250 councils but only 12 mayors.)

Predetermination rules continue to be strongly enforced in New Zealand, to the consternation of many elected members who campaign on issues but find they cannot vote on them. Registers are discretionary in New Zealand local government but many councils have incorporated them in their codes of conduct. 


\begin{tabular}{|c|c|c|}
\hline Headings & Content & Relevance to New Zealand \\
\hline Housing targets & $\begin{array}{l}\text { Regional spatial strategies - aimed at building three million homes by } 2020 \text { - are } \\
\text { being scrapped. The Localism Bill will remove the primary legislation which set up the } \\
\text { strategies. The government says construction has slowed down despite what it calls } \\
\text { 'Soviet tractor-style top-down planning targets'. }\end{array}$ & $\begin{array}{l}\text { The requirement to develop a spatial strategy has been placed } \\
\text { on the Auckland Council. The Ministry for the Environment is } \\
\text { considering mechanisms to require councils to make more } \\
\text { land available for housing regardless of community views. }\end{array}$ \\
\hline $\begin{array}{l}\text { Charges on } \\
\text { developers }\end{array}$ & $\begin{array}{l}\text { The bill makes changes to the 'community infrastructure levy' which councils charge } \\
\text { developers to contribute towards local infrastructure - to ensure some money goes } \\
\text { directly to the neighbourhood where developments have been built, so that it can be } \\
\text { spent on local facilities such as cycle paths or playgrounds if needed. }\end{array}$ & $\begin{array}{l}\text { There are some similarities between this requirement and the } \\
\text { ability of New Zealand councils to charge development levies } \\
\text { to enhance community facilities to meet additional demand } \\
\text { created by new developments. }\end{array}$ \\
\hline Local development & $\begin{array}{l}\text { The bill introduces 'neighbourhood plans'. The idea is that parish councils and } \\
\text { 'neighbourhood forums' come together to decide where new shops, offices or homes } \\
\text { should go and what green spaces to protect - which is then voted on by local people } \\
\text { in local referendums. They will be able to define developments which should have } \\
\text { automatic planning permission. }\end{array}$ & $\begin{array}{l}\text { No equivalent exists in New Zealand, although councils must } \\
\text { consult when developing plans and can involve community } \\
\text { boards in the process. }\end{array}$ \\
\hline Planning permission & $\begin{array}{l}\text { Local communities will be able to propose developments which, if they meet certain } \\
\text { safeguards and get } 50 \% \text { of support in a local referendum, they will be able to build } \\
\text { without planning permission. This is aimed at tackling lack of building in rural areas } \\
\text { where planning authorities restrict building but local people want new housing or other } \\
\text { facilities. Also, big developments will require early consultation with local people. The } \\
\text { bill also confirms the abolition of the Infrastructure Planning Commission - instead } \\
\text { ministers will make decisions on big planning projects such as airports and wind farms. }\end{array}$ & $\begin{array}{l}\text { No similar ability exists in New Zealand. In relation to } \\
\text { decisions on major projects of national significance, decisions } \\
\text { are made through the EPA process. }\end{array}$ \\
\hline
\end{tabular}

\section{References}

Bailey, S.J. (1999) Local Government Economics: principles and practice, Basingstoke: Palgrave Macmillan

Cabinet Office (2011) 'Big Society - overview', http://www.cabinetoffice. gov.uk/content/big-society-overview

Cameron, D. (2009a) http://blog.lgiu.org.uk/2009/02/david-cameron-onlocalism

Cameron, D. (2009b) www.guardian.co.uk/commentisfree/2009/davidcameron-on-new-politics2

Carman, A. (1970) The Birth of a City, Wellington: Wright and Carman Ltd

Cashin, S. (2000) 'Localism, self-interest and the tyranny of the favored quarter: addressing the barriers to new regionalism', Georgetown Law Journal, 88, pp.1985-2048

Cookson, J. (2007) 'How British? Local government in New Zealand to c.1930', New Zealand Journal of History, 41 (2), pp.143-60

Department for Communities and Local Government (2010) 'Localism Bill starts new era of people power', http://www.communities.gov.uk/ news/newsroom/1794971
Dollery, B., A. Akimov and J. Byrnes (2005) Shared Services in Australian Local Government: rationale, alternative models and empirical evidence, Armidale, New South Wales: Centre for Local Government, University of New England

Filkin, G., G. Stoker, G. Wilkinson and J. Williams (2000) Towards a New Localism, London: New Local Government Network

Lyons, M. (2007) Place-shaping: a shared ambition for the future of local government, final report, London: The Stationery Office

Novak, M. (1996) To Empower People: from state to civil society, 20th century edition, Washington, DC: AEI Press

Royal Commission on Social Policy (1988) Towards a Fair and Just Society, Wellington: Royal Commission on Social Policy

Stoker, G. (2004) New Localism, Participation and Networked Community Governance, Manchester: IPEG, University of Manchester 